\title{
Regional Plannning Strategic of Irrigated Agricultural Land Convertion by Considering to The Irrigation System (Case Study: Cihea Irrigation System of Cianjur)
}

\author{
Endang Purnama Dewi ${ }^{\# 1}$, M.Yanuar J Purwanto ${ }^{\# 2}$, Asep Sapei ${ }^{\#}$ \\ \# Department of Civil and Environmental Engineering, Bogor Agricultural University (IPB), Bogor, Indonesia \\ E-mail: ${ }^{1}$ endangpurnamadewi.33@gmail.com, ${ }^{2}$ yanuar.tta@gmail.com
}

\begin{abstract}
Regional development is targeted to make better growth in the rural area, by improving farmer's welfare and minimizing the gap among the regions. In particular, the developement aims to increase farmers income percapita as an income indicators of developement in rural area. In the irrigation area, the regional development can also increase the domestic revenue by providing value added program in this region. The existing regional plan (RTRW) of Cianjur in 2013 -2031 a part of the study area (Cihea irrigation system) are planned to be converted in to industrial area, it reaches $\mathbf{4 2 0 9 . 9 0 3}$ ha. This research aims to provide an irrigation system based developement strategy for guiding to the implementation of the RTRW. In the irrigation system, there are water resources and agricultural activities, mostly in food comodities. These resources will be considered in the study in order to achieve the target of rural development as for the implemention of RTRW. In this research, it analyzed suply and demand of irrigation, based on water balance calculation and farm production, the prospective industrial area in the region for processing the raw product of farming. As the result, The agricultural land convertion should be targeted into processing plant for rice and soy. By these scenarios, the water resources were able to irrigate area of 5484 ha with cropping pattern of rice-rice -secondary foodcrop as the minimum discharge occured in September its about $0.553 \mathrm{~m} 3 / \mathrm{second}$. The total production of this raw agricultural product can be processed to rice snack and cereal beisde of rice, thus being able to gave rise in income of farmer to Rp2 461 706,- per planting season.based on spatial analyze, the area which is can be developed are Ciranjang, Sukaratu, Sindangjaya, Mekargalih, Bojongpicung, Kertajaya, dan Cibiuk.
\end{abstract}

Keywords - regional developement,converted land, irrigation of cihea, percapita income

\section{INTRODUCTION}

Rural developement based on leading commodity do not take continue processing of commodities, therefore, the developement based on irrigation system is an alternative solution to develope an area based on the utilization of water and land resources.this area is defined as a functional system which is showed by system which is indicated villages of rural spatial hierarchy and presence of downstream industries for agricultural products. In addition, this area is also characterized by the agricultural area that grows and develops due to the operation system and agribusiness are expected to serve and encourage the development of agricultural activities in the surrounding area.

According to RTRW (Planning of spatial Cianjur) 2013, Cihea Irrigation system wiill be converted partially which is irrigated land will be used as industrial area. Therefore it takes a study to analyze the use of land can be developed, but there is no negative impact on irrigated rice farmers and jobs. Basically every region has the potential of land and resource conditions which are different from each other. Proper land use will not have an impact on people's income or region. And conversely areas with the management of land and water resources are appropriate to increase the quantity and quality of agricultural products and can be processed into downstream products which have high added value so that the revenue generated was greater. Agriculture is a sector basis of Cianjur economic development. However at this time, the agricultural sector has not evolved towards supporting the processing of agricultural industrialization which is a more advanced stage of development of the agricultural sector alone, and industries producing agricultural inputs. Some of the things that shows, among other things related to land use, farmers, production and distribution. By looking at the regional gross domestic (GDP) which is the largest $47.65 \%$. It shows that the development of the district of Cianjur attention should be more focused on agriculture. In case this is not still have to maintain the 
existence of agriculture with all the traditional characteristics, but should be more directed to the transformation of modern or industrialized agriculture is able to provide added value to the agricultural sector. Austin (1992) stated that the reason for the development of industries, especially agro-industry is needed because the agriculture sector requires extractive industry that is able to process all the results of the agricultural and industrial sectors in need of raw materials in the treatment process.

In rural agricultural areas in paddy fields irrigated land is found technically - land that is not utilized, while in terms of availability of water irrigation areas should be used optimally with high land productivity. In addition, farmers are generally income derived from the sale of rice is relatively lower selling price than the selling price of rice. This leads to the advantage of farmers is relatively small and can not meet the needs of decent living. Raises some questions in order to improve the welfare of farmers in the irrigation area of Cianjur Cihea farmers in particular and Indonesia in general well-being, namely: (1) How does the availability of water in irrigated areas (2) How does the irrigation area development scenarios that could improve the welfare of farmers (3) what are the downstream products could be developed from the industry in the agricultural sector.

\section{RESEARCH METHOD}

\section{A. Time and Place}

This study was carried out in September 2013 to February 2014. This research was taken in Cihea Irrigation System in Cianjur, West Java.

\section{B. Materials and Instruments}

The instruments were used in this research is used to analyzed spatial process. The tools used to study the device to process the spatial data and observation in the field that each device comprising: camera, computer equipment, the type of Garmin GPS, software which is used : ArcGIS 9.3 software to process spatial data, device Google Earth software for digitizing, software Microsoft Office 2010 for writing a thesis and data processing. Materials are processed in this research consisted of hydrological data in the form of rainfall and discharge data, land use data in the study site, under Digital Elevation Model (DEM) data network infrastructure of irrigation and socio-economic data in Cianjur.

\section{Procedure of research}

In this study, the determination of the development area is done through five stages, which are: 1) identification of Irrigation Area coverage Cihea Cianjur 2) data preparation; 3) determine priorities for each criteria regional development; 4) determine the area that may be developed. The stages of this research can be seen in Figure 1.

\section{1) Analysis of the availability of irrigation water sources}

Availability of water watersheds in principle shows the potential discharge of river water with certain opportunities (Ministry of Public Works, SK SNI, 1993). Calculated based on the formula Probability (Chance) on daily discharge data for the last 10 years.
Irrigation water demand is determined by factors such as land preparation, consumptive use, percolation, replacement of the water layer and effective rainfall and irrigation efficiency (KP-01 1986)

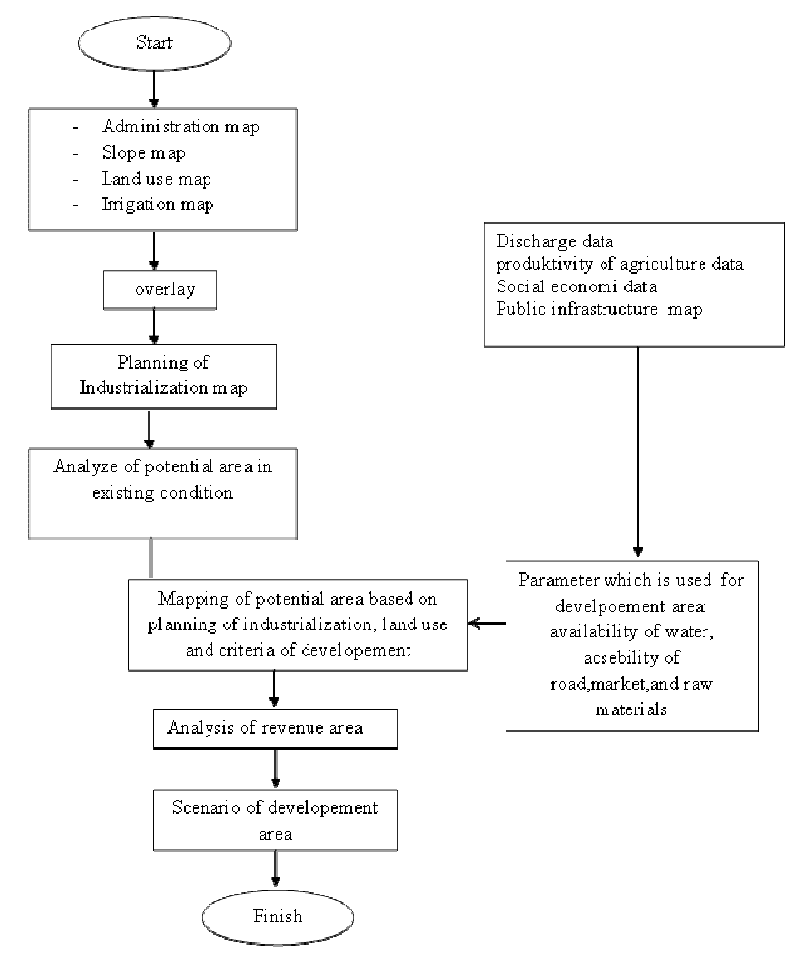

Fig.1 Diagram step of the research

\section{2) Analysis of revenue}

Analysis of revenue calculated based on downstream productivity as well as for the comparison before and after the conversion of the region.

The model equations of the revenue function is described mathematically

$$
R=C_{L} \times f(L)
$$

where $R$ is the revenue of a region in units of dollars, $C_{L}$ is the coefficient of land productivity (constant), and L states land area in hectares (Friday Nur, 2012).

3) Analysis of the determination of the optimal area of an industrial area

Analysis of revenue is calculated based on the scenario and the region have been calculated. Approach to an industrial area that had added value to the crop as a source of raw material for value-added will be the basis of the needs of land conversion. Meeting point between the extent of crop and area requirements of industrial land is a broad optimum.

\section{4) Spatial analysis.}

Spatial analysis to determine the productivity of the region and the optimal location of the area was done by using superimposed (overlay) with the scoring method based on the parameters that have an influence on the development of the region. 


\section{RESULT AND DISCUSSION}

\section{A. General conditions of the study site}

Farmers in Cianjur Cihea are farmers with paddy and pulses. Cropping intensity is two times and 1 time planting rice planting crops in a year. Rice varieties which is used are Ciherang, Mekongga and IR 64. The average production is 5.6 tons per hectare with a production cost of Rp 3,000,000 per hectare. Cultivated crops are soybeans. The varieties used are Argo Mulyo, Anjasmoro, MS Dapros, Burangrang and Raja Basa. The average production of 1.5 tons / hectare.

Irrigation Area of Cihea is a plain area which is administratively located in 3 subdistrict ie bojongpicung, Haurwangi and Ciranjang (Figure 2) with a total area of 5484 ha of irrigated rice fields.

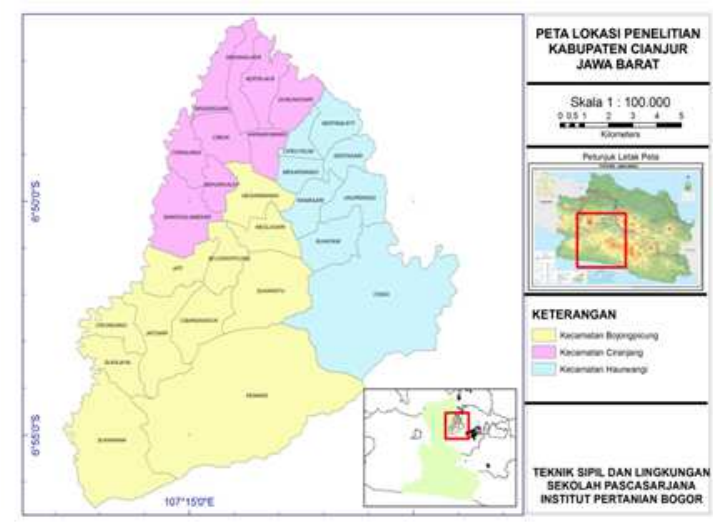

Fig.2 Map of the study site

The slope of the land is a certain height difference on the relief available to a landform . Determination of the average slope of the land in each group mapping can be done by making the relationship between the points. The length of the line shows the same slope. The slope of the land shows the character of the area that should be considered in the direction of land use. Slope of each region is different but in general can be classified into several groups. The slope of the land affected by the height of land to the sea because it was getting close to the sea tend to be flat. The area in this study is in interval 0-8\% more can be seen in Table 1

TABLE I

DESCRIPTION OF SLOPE IN IRRIGATION CIHEA SYSTEM

\begin{tabular}{|c|c|c|c|}
\hline $\begin{array}{c}\text { Class } \\
\text { interval }\end{array}$ & Interval (\%) & Description & Wide (ha) \\
\hline 1 & $0-8$ & Flat & 19049 \\
2 & $8-15$ & Ramps & 4036 \\
3 & $15-25$ & Little steep & 2665 \\
4 & $25-40$ & Steep & 3114 \\
5 & $>40$ & Extremely & \\
& & steep & 2735 \\
\hline
\end{tabular}

\section{B. Pattern space of Cianjur}

Allotment of industrial area is the area that can technically used for industrial activities that can take place in a productive and efficient, and does not interfere with the preservation of the environment. Based Spatial pattern space Cianjur 2013 - 2031 the areas designated as the industry can be seen on the map ( Figure 3 ). These areas are Cihea Irrigation Area which is basically an agricultural area.

Transfer function for the agricultural area should not be done as this will impact on the provision of food, especially rice. Therefore, in order to synergize the industrial area plan , the industry is supposed to be there so that the agriculturebased processing industry of agricultural areas can still be maintained.

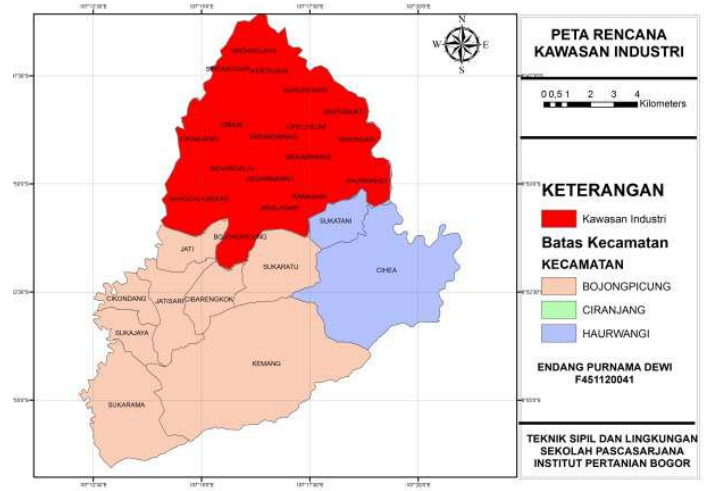

Fig. 3 The industrial area plan map

Based on the industrial area plan map (Fig.3), the obtained regions are planned based Spatial Cianjur (table 2).

TABLE II

THE AREA THAT WILL BE CONVERSED BECOME INDUSTRY

\begin{tabular}{|l|l|}
\hline Name of sub district & wide (ha) \\
\hline Haurwangi & 1132.932 \\
Bojongpicung & 1544.203 \\
Ciranjang & 1529.792 \\
\hline
\end{tabular}

\section{Planning and value-added downstream industries}

Associated with post-harvest activities are directed primarily in an effort to increase the added value through the application of appropriate technology to aid further processing. This will result in increased production and selling prices has implications for the improvement of social and economic life of farmers and the general public. Here also the government policies are needed in order to add value in this post-harvest can be enjoyed by farmers. According Jayadinata (1999) that the activities of industrial production ( manufactural industries ) are human activities in transforming raw materials into more useful goods or industrial goods, ie semi-finished goods and finished goods. In industrial activity there will be value addition or value adding . Based on the productivity of each district in the Cihea irrigation area with paddy agriculture is one sector that could be developed. By product of rice that can be used in the form of processed rice groats and chiki in the form of cereal.

Rice Milling Unit ( RMU ) is one means of processing off farm in rice postharvest handling . Capacity and number of rice mills can not supply the needs of farmers, the number of rice mills today is 107 mill with a capacity of 9900 tons/year and 31 rice mills with a capacity of 5000 tons/year ( Department of Agriculture , 2010 ). In this study, it will made the planning of a place that can accommodate a rice mill production capacity around Cihea Irrigation Area. For 
planning Rice Milling Unit ( RMU ) in the irrigation area Cihea with consideration of raw materials and the area to be converted then the extent of conversion which is $16 \%$ need RMU 72 units with a capacity of 700-1000 kg / hour.

\section{Analysis of revenue based on regional productivity}

Regional economic development in principle, aims to improve the welfare of the one measured in GDP indicators rise or increase in regional income per capita. If real per capita income increases, there will be an increase in the economic welfare of the community. The progress experienced by an area can be seen from the magnitude of the resulting economic growth . Rate of economic growth is one of the many sets of indicators that show an increase in the standard of living and welfare of the population as a result of development.

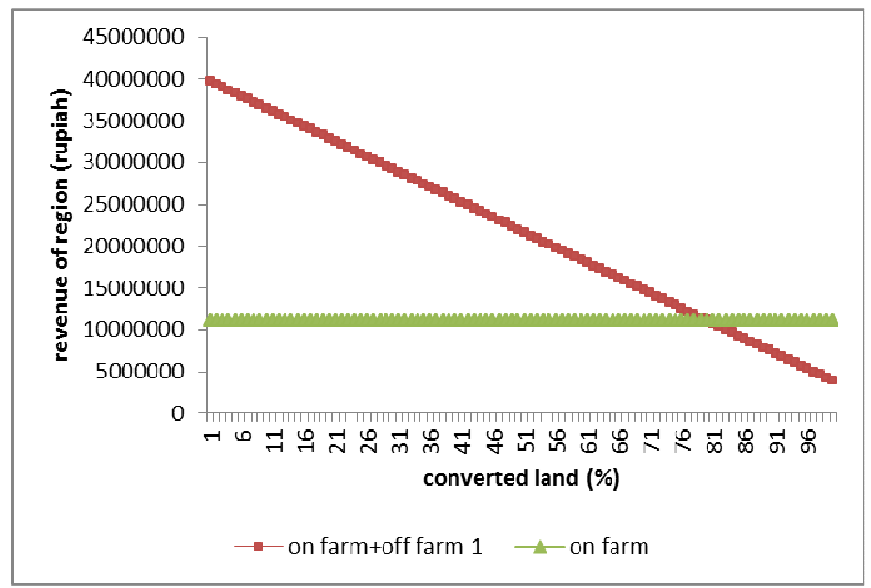

Fig.4 revenue with scenario 2

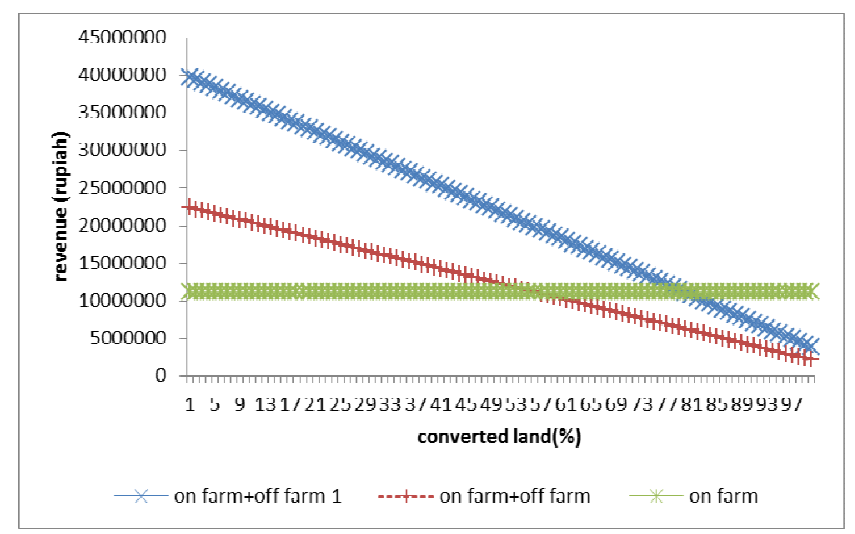

Fig. 5 Comparison between scenario 1 and 2

Based on the graph above shows that the existing condition without the scenario so that the revenue obtained is static, which is shown by the graph on farm only (figure 4 ). But if done scenario 1 with processed groats (on farm + off farm) region revenue would be 2 times with the amount of Rp22.400.000 and if it is done that is the scenario 2 with the addition of rice bran processing RMU there will be an increase in the revenue to be $\mathrm{Rp} 39.760 .000$ (figure 5). By the analysis conducted on several scenarios above, the conversion is not necessary to obtain optimal revenue region, it because when the conversion is done more widely, it make less the amount of raw materials . Spatial Planning and Regional (Spatial) Cianjur district will make the industrial area is 4209,903 ha. After calculation and analysis, the extent required to convert only $16 \%$. (Figure 6)

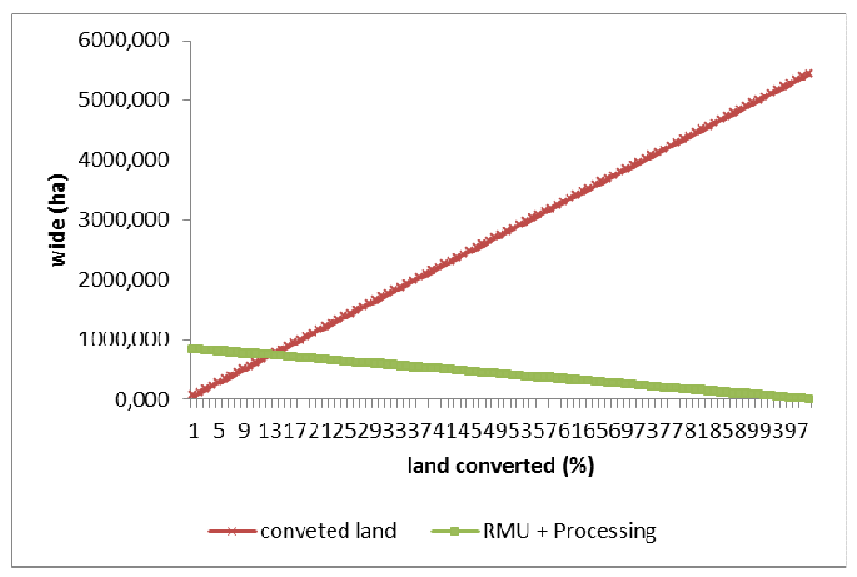

Fig.6 Land wide optimum to be converted

Based on the calculation and analysis, the optimal area to be converted into an industrial area only $16 \%$ with revenue area is Rp19.336.543 for scenario 1 and Rp34.322.363 for scenario 2. The extent of these conversions, the planning area for Rice Milling Unit and Industry ( processing ) that is required is an area of 257,96 ha and 460,66 ha .

\section{E. Analysis of supply and demand for irrigation water}

Irrigation Area Cihea included into the irrigation area (DI) water source is derived from the River of Cisokan. According to records from the Department of Water Resources and Mines, Cisokan river channeled into irrigation canals to irrigate the land area in DI Cihea technical regulated through Cisokan weir which is located in Sukarama.The functional area of land devoted to rice crops in DI Cihea is $5484 \mathrm{Ha}$.

To calculate the availability of irrigation water that will be used to irrigate the paddy fields by calculating the average amount of discharge of river water into the channel for 10 years (2002-2012). Amount of water discharge is also influenced by rainfall that occurred in the vicinity of irrigation. Rainfall averages region represents the location of the study area is presented in Figure 7

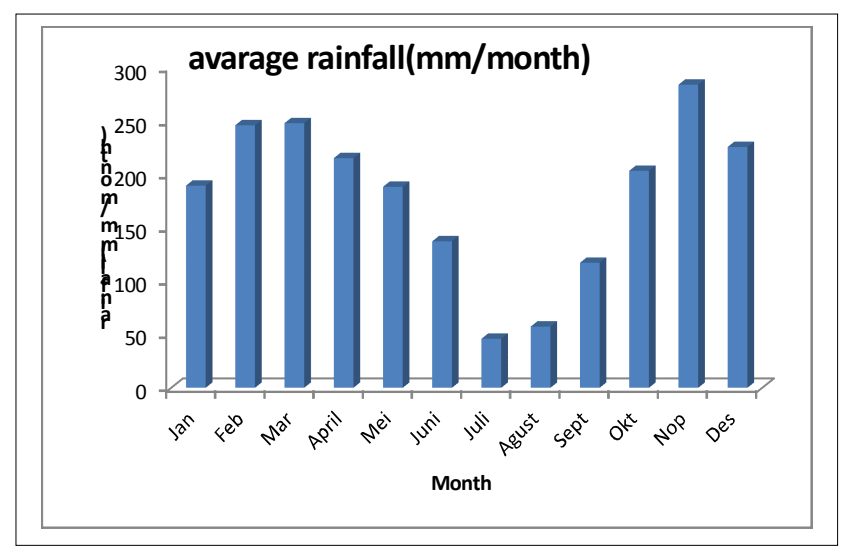

Fig.7 Graph of avarage rainfall 
According to the climate classification of Oldeman methode based wet months and dry months, the irrigation area Cihea included in climate type D that climate has a wet month 3-4 times in a row. the highest rainfall in the month of November is $283.708 \mathrm{~mm}$ and the lowest in July is 45 . $917 \mathrm{~mm}$. The following flow chart presented mainstay and the existing water balance Cihea Irrigation Area.

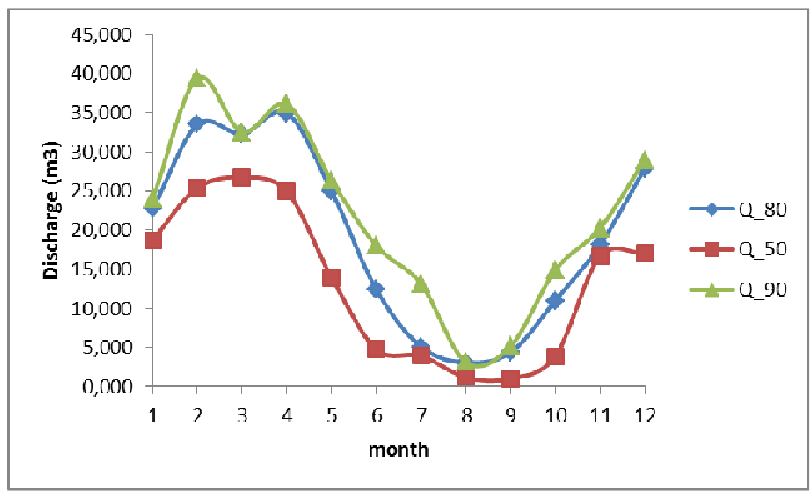

Fig.8 graph of mainstay discharge

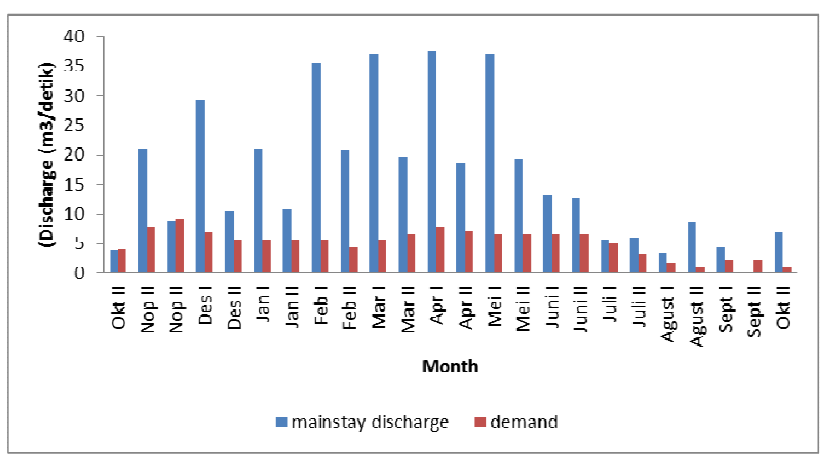

Fig.9 graph of water balance

$\mathrm{Q}_{80}$ occured in the maximum discharge at $20,008 \mathrm{~m}^{3} / \mathrm{s}$ in February and a minimum flow occurs in September in the amount of $0,553 \mathrm{~m}^{3} / \mathrm{sec}$. With the number of existing discharge, water demands can be met and excess in november first through to May, but in the months of May second to October second water shortage occurs. It can be seen from the graph of the existing water balance (Figure 9).

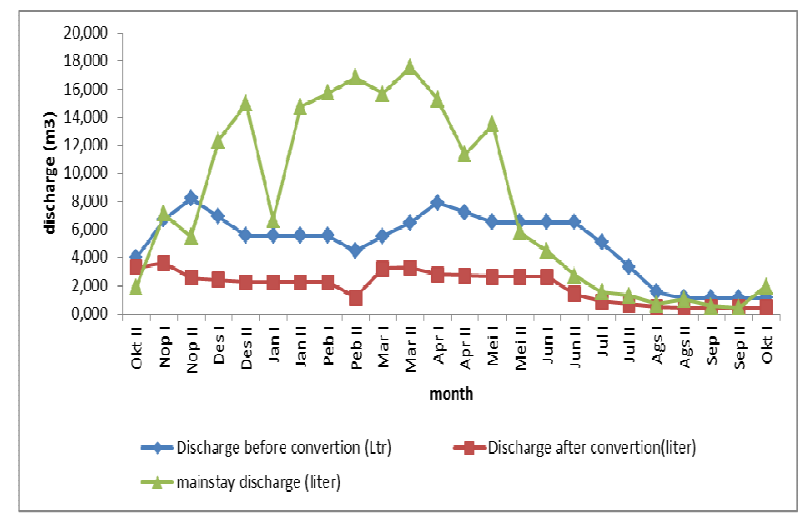

Fig.10 Graph comparing demand of water before and after convertion

\section{F. Siting Industrial Estate}

Based on the literature review, the development of appropriate criteria for the region consisting of the technical criteria include accessibility roads, the distance the region to the market, flood prone areas, infrastructure and energy (Adisasmita 2010). Based on Spatial Cianjur district, area which will be used as industrial area is the area which is resulting in the use of rice cultivation and utilization shall be in accordance with Law No. 26 Year 2007 on spatial planning. Here is a map overlay based on the parameters and criteria that have been made. To determine the location of the development of agro-industry region scoring method is used. scoring is done based on the criteria that have been predetermined.
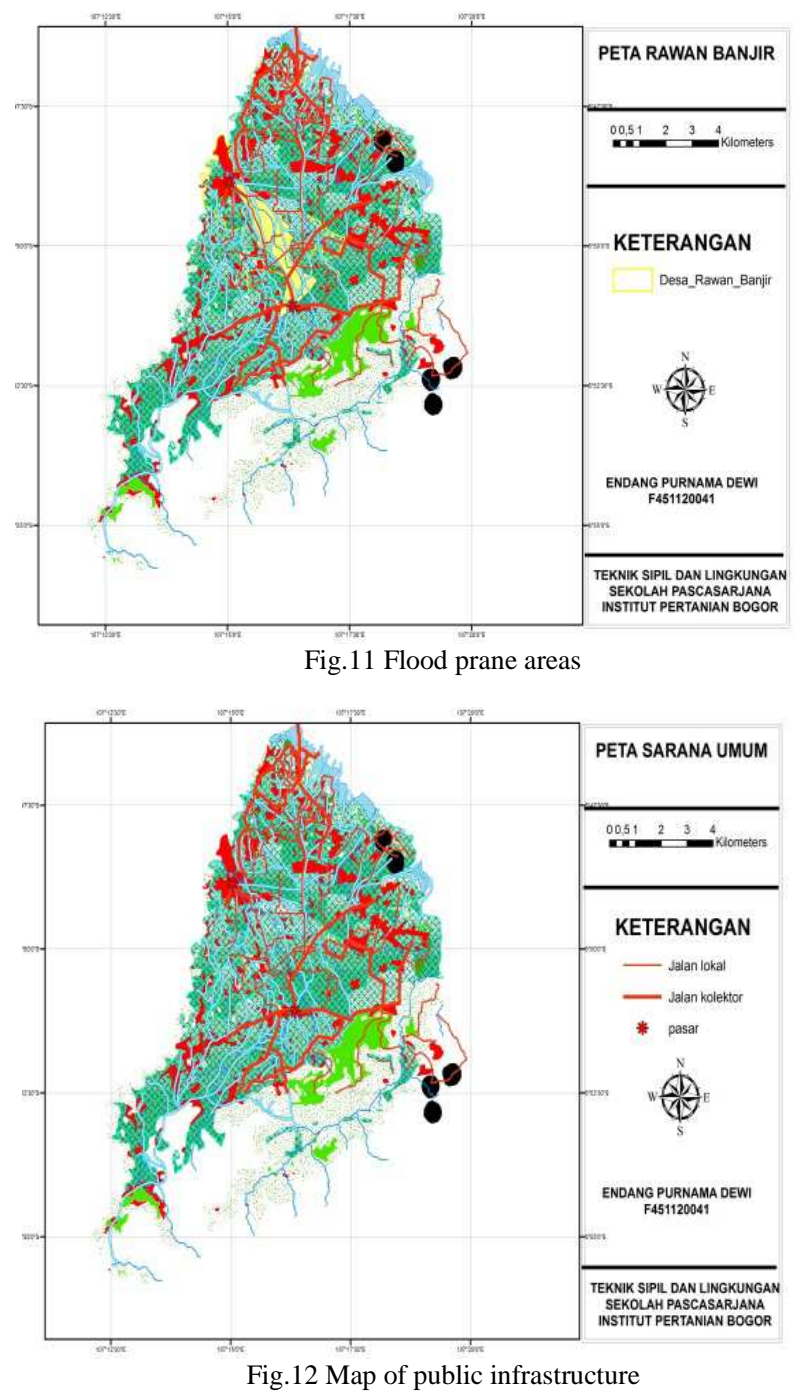

Scoring is done on the factors that have been predetermined in each district so that it will find the location of districts with the greatest score as the sub-district with the potential to be developed into agro-industry region.

Based on the weighting method on several factors such as raw materials, markets, roads, infrastructure and energy can then be obtained village. conducted development as an industrial area that is Ciranjang (scored 14), Sukaratu (scored 14), Sindangjaya (scored 12), Cibiuk (scored 11), 
Bojongpicung (scored 11), Kertajaya (scored 11), and Karangwangi (scored 12).

\section{CONCLUSIONS}

Results of measurements in the laboratory showed that : Irrigation Area Cihea is a potential area for development viewed from the availability of water resources at the time of discharge mainstay $\left(\mathrm{Q}_{80}\right)$ maximum flow is equal to 20,008 $\mathrm{m}^{3} / \mathrm{sec}$ and a minimum flow of $0553 \mathrm{~m}^{3} / \mathrm{sec}$. Cihea potential irrigation area developed with a leading commodity rice with regional revenue during the first scenario will be increased to Rp22.400.000, while the second scenario then an increase in revenue be Rp39. 760.000. For technical land industrial area with an area that is converted by $16 \%$ then the area required for Rice Milling Unit (RMU) covering an area of 257,96 ha and 46,.66 ha processing. Based on the analysis of the spatial overlay method and scoring factors - factors to determine the location of the local area that can be used as a location for industrial development is Ciranjang, Sukaratu, Sindangjaya, Mekargalih, Bojongpicung, Kertajaya, and Cibiuk.

\section{REFERENCES}

[1] Adisasmita,Rahardjo.2010 Pembangunan kawasan dan tata ruang edisi pertama. Graha Ilmu : Yogyakarta

[2] Austin J.E. 1992. An Agroindustrial Project Analysis. Critical Design Factors. EDI Series in Economic Development. The John Hopkinds University Press, Baltimore and London

[3] [BAPPEDA] Badan Perencanaan dan Pembangunan Daerah.Kabupaten Cianjur Dalam Angka.2013.Badan Perencanaan Kabupaten Cianjur.BAPPEDA Kabupaten Cianjur : Cianjur

[4] Departemen Pekerjaan Umum, 1993, SK SN. Kementrian Pekerjaan Umum : Jakarta

[5] Dinas Pertanian. 2006. Laporan Tahunan 2000-2010. Dinas Pertanian Kabupaten Cianjur.

[6] Jayadinata,J.T.1999.Tata Guna Tanah dalam Perencanaan Perdesaan,Perkotaan dan Wilayah. Penerbit ITB : Bandung

[7] Nur friday et al.2012. Studi Penetapan Kebutuhan Lahan Teknis Sebagai Penggerak Pembangunan Desa Menuju Kawasan Agro Industri di Kabupaten Konawe, Sulawesi Tenggara. Jurnal irigasi vol 2 tahun 2012. Balai Irigasi : Bekasi

[8] Soewarno, 1995. Hidrologi Aplikasi Metode Statistik untuk Analisa Data, Jilid 1 Nova : Bandung 